\title{
PEMANFAATAN TEKNOLOGI INFORMASI DAN KOMUNIKASI UNTUK PENGEMBANGAN EKONOMI PERTANIAN DAN PENGENTASAN KEMISKINAN
}

\author{
Utilization of Information and Communication Technology for Development of \\ Agricultural Economics and Poverty Reduction
}

\author{
Ahmad Badari Burhan \\ Fakultas Ilmu Komunikasi Universitas Pancasila \\ E-mail: ahmadbadariburhan@univpancasila.ac.id
}

\begin{abstract}
This study is intended to gain a better understanding of the use of ICTs from several developing countries for the purpose of developing agricultural economics and poverty alleviation. From the lessons learned, it is expected to get opportunities and challenges that must be addressed in relation to the use of ICTs for the development of agricultural economics and poverty alleviation, especially in Indonesia. The literature study method from several developing countries shows that ICTs play a role in helping farmers in decision making, in terms of planting and harvesting time because this is important in agricultural development. In this case, ICT empowers farmers with productive assets and marketing, increasing their productive capacity so that reducing their poverty status. Affordable ICT services in rural communities have played a very strong role in improving the economic conditions of the population that contribute to the rural economy. ICTs have the potential to be effective instruments in supporting poverty alleviation. In Indonesia, ICTs have not been used properly for agricultural business development because of the low level of education in agricultural business households and access to information on internet media. To overcome the information gap for rural households/ communities is to make the extension officers more effective, accelerate the development of telecommunications infrastructure in order to strengthen telecommunications signals, and provide continuous support to rural farmers and agricultural businesses.
\end{abstract}

Keywords: developing countries, rural areas, agricultural economic development, poverty alleviation, information and communication technology

\begin{abstract}
ABSTRAK
Studi ini dimaksudkan untuk mendapatkan pemahaman yang lebih baik terkait dengan pemanfaatan TIK dari beberapa negara berkembang untuk tujuan pengembangan ekonomi pertanian dan pengentasan kemiskinan. Dari lessons learned, diharapkan mendapatkan peluang dan tantangan yang harus disolusikan terkait dengan pemanfaatan TIK untuk pengembangan ekonomi pertanian dan pengentasan kemiskinan, khususnya di Indonesia. Dengan metode studi literatur dari beberapa negaraberkembang menunjukkan bahwa TIK memainkan peranan membantu petani dalam pengambilan keputusan, dalam kaitannya dengan waktu penanaman dan panen karena ini penting dalam pembangunan pertanian.Dalam hal ini, TIK memberdayakan petani dengan aset produktif dan pemasaran, meningkatkan kapasitas produktif mereka sehingga mengurangi status kemiskinan mereka.Layanan TIK yang terjangkau di masyarakat pedesaan telah memainkan peran yang sangat kuat dalam meningkatkan kondisi ekonomi penduduk yang berkontribusi pada ekonomi pedesaan.TIK memiliki potensi untuk menjadi instrumen yang efektif dalam mendukung pengentasan kemiskinan. Di Indonesia, TIK belum dimanfaatkan secara baik untuk pengembangan usaha pertanian karena rendahnya tingkat pendidikan rumah tangga usaha pertanian dan akses informasi terhadap media internet. Untuk mengatasi kesenjangan informasi bagi rumah tangga/masyarakat desa adalah dengan lebih mengefektifkan petugas penyuluh lapangan, mengakselerasi pembangunan
\end{abstract}


infrastruktur telekomunikasi dalam rangka penguatan signal telekomunikasi, dan memberikan dukungan secara terus-menerus kepada petani pedesaan dan usaha pertanian.

Kata kunci: negara berkembang, pedesaan,pembangungan ekonomi pertanian, pengentasan kemiskinan, teknologi informasi dan komunikasi

\section{PENDAHULUAN}

Teknologi informasi dan komunikasi atau TIK (Information Communication Technology, ICT) didefinisikan sebagai serangkaian kegiatan yang difasilitasi oleh sarana elektronik melalui pemrosesan, transmisi dan tampilan informasi (ADB, 2003). TIK adalah penggunaan teknologi modern untuk membantu penangkapan, pemrosesan, penyimpanan dan pengambilan, dan komunikasi informasi, baik dalam bentuk data numerik, teks, suara, atau gambar (Rahman, Abdullah, Haroon Tooheen, 2013). TIK dapat digunakan untuk menghubungkan perangkat teknologi informasi seperti komputer pribadi, dengan teknologi komunikasi seperti telepon dan jaringan telekomunikasi (Greenidge, 2003). Dalam perkembangannya, TIK telah mengambil dimensi yang lebih luas yang meliputi banyak media seperti telepon, televisi, radio, video, teleks, sistem informasi suara, faks, komputer pribadi dan internet (Adeniyi, 2010).

TIK berperan sebagai enabler dalam transformasi sosial budaya di berbagai aspek kehidupan masyarakat sekaligusmerupakan sektor pendorong utama pertumbuhan ekonomi masyarakat.TIK akan membantu dalam upaya membuka isolasi wilayah pedesaan terhadap informasi pasar, modal, inovasi pertanian serta sarana dan prasarana pendukung lainnya. TIK memfasilitasi (a) diseminasi informasi dan akses terhadap informasi yang memiliki nilai tambah, (b) proses berbagi pengetahuan (knowledge sharing), (c) pengembangan keterampilan, kapasitas, dan kompetensi; (d) pengembangan jaringan komunikasi (communication networks); dan (e) pembangunan ekonomi pertanian dan pedesaan. Upaya-upaya membangun Indonesia dari pinggiran dan peningkatan daya saing ekonomi, serta upaya-upaya pemberdayaan masyarakat di wilayah pedesaan semestinya dapat diakselerasi melalui pemanfaatan TIK.

TIK dapat menjadi solusi untuk masalah mengakses berbagai sumber informasi yang terjangkau,relevan, dan dapat diandalkan oleh petani (Madukwe 2006). TIK memfasilitasi ketepatan waktu penyampaian penyuluhan, memanfaatkan kecepatan pemrosesan elektronik-antara lain mentransmisikan, menyimpan dan mengambil informasi dan melindungi data (Madukwe 2006).TIK dapat membantu petani dalam proses pengambilan keputusan, kepemilikan lahan pertanian dan perjanjian sewa guna usaha, ekonomi mesin dan pemasaran produk (Leary dan Berge 2006). TIK membantu petani memerangi dan menciptakan kesadaran tentang hama dan penyakit pertanian. Hal ini jika dikelola dengan baik akan meningkatkan produksi pertanian, meningkatkan pendapatan petani, dan selanjutnya mengurangi kemiskinan di kalangan petani pedesaan (Leary dan Berge, 2006).

Sebagian besar orang miskin tinggal di daerah pedesaan dan memperoleh mata pencaharian mereka secara langsung atau tidak langsung dari pertanian, oleh karena itu dukungan untuk pertanian merupakan prioritas tinggi untuk pembangunan pedesaan (Harris, 2002).Kemiskinan bukan hanya ekspresi kondisi kehidupan, tetapi keadaan pikiran dan persepsi diri dalam jejaring sosial yang kompleks (Leary dan Berge, 2006). Orang miskin adalah mereka yang bukan 
hanya tidak memiliki sumber daya material dan keuangan, tetapi juga tidak memiliki kesempatan untuk mengubah sumber daya yang mereka miliki (tenaga kerja, keterampilan/pengalaman dan sumber daya fisik) dalam kegiatan menciptakan nilai, sehingga menghasilkan pendapatan atau menghasilkan sumber daya lain yang berharga untuk mata pencaharian/ penghidupan mereka yang khusus (McNamara 2003).

Petani memerlukan pengetahuan dan informasi mengenai berbagai topik, seperti: pengelolaan usaha tani dan teknologi produksi, pengalaman petani lain, perkembangan pasar dan input produksi, dan kebijakan pemerintah (Mulyandari dan Ananto, 2005). TIK dalam sektor pertanian yang tepat waktu dan relevan memberikan informasi yang tepat guna kepada rumah tangga usaha pertanian untuk pengambilan keputusan dalam berusaha tani, sehingga efektif dalam meningkatkan produktivitas, produksi, dan keuntungan.

Informasi dan pengetahuan merupakan komponen penting dari strategi pengentasan kemiskinan, dan TIK menawarkan janji akses mudah ke sejumlah besar informasi yang berguna bagi orang miskin (Harris 2002). Pemanfaatan TIK pada sektor pertanian akan menjadi pemicu dalam menciptakan peluang untuk pembangunan pertanian dan ekonomi sehingga terjadi pengurangan kemiskinan.

Selain itu, dunia pertanian semakin padat pengetahuan (knowledge intensive). Akses terhadap inovasi pertanian yang memadai dan tepat waktu didukung informasi pertanian terkait lainnya dapat digunakan sebagai input dalam proses pengambilan keputusanuntuk pengembangan usaha tani. Namun demikian, penggunaan TIK dan akses terhadap informasi untuk pengembangan ekonomi pertanian mungkin akan menjumpai sejumlah tantangan karena pertanian di Indonesia dikuasai oleh petani kecil di kawasan pedesaan dengan produk pertanian dan mutu yang bervariasi dan mereka sebagian besar berada pada kondisi kemiskinan. Petani kecil antara lain memiliki keterbatasan aksesibilitas terhadap permodalan, pengetahuan, informasi pasar dan inovasi pertanian, serta keterbatasan dalam penguasaan lahan, keterampilan, dan posisi tawar terhadap pasar (Mulyandari, Sumardjo, Lubis, dan Panjaitan 2010).

Rendahnya tingkat kemampuan petani untuk membuka diri terhadap suatu pembaharuan dan atau informasi yang berkaitan dengan unsur pembaharuan juga semakin memperburuk kondisi petani dalam membuat keputusan untuk menolak atau menerima inovasi (Mulyandari, Sumardjo, Lubis, dan Panjaitan 2010). Selain itu, hasil survei akses dan penggunaan TIK oleh rumah tangga dan individu di Indonesia tahun 2014 menunjukkan bahwa sebagian besar TIK, seperti pemanfaatan radio dan televisi masih lebih banyak dimanfaatkan untuk keperluan hiburan. Internet juga lebih banyak digunakan untuk mengakses media sosial.Perilaku ini hampir merata pada setiap jenis pekerjaan.Penggunaan TIK untuk kepentingan hiburan, semakin besar pada responden berpendidikan rendah (Kementerian Komunikasi dan Informatika RI 2015).

Pertanian menjadi andalan ekonomi pedesaan, oleh karena itu penting untuk mencari cara-cara mengurangi situasi kemiskinan petani di perdesaan dengan menanggulangi semua masalah yang mungkin mereka hadapi dalam kegiatan produktif.TIK menawarkan solusi untuk mengurangi kesenjangan informasi dengan menyediakan informasi yang tepat bagi petani di pedesaan.

Studi ini dimaksudkan untuk mendapatkan pemahaman yang lebih baik terkait dengan pemanfaatan TIK dari beberapa negara berkembang untuk tujuan 
pengembangan ekonomi pertanian dan pengentasan kemiskinan. Dari lessons learned, diharapkan mendapatkan peluang dan tantangan yang harus disolusikan terkait dengan penggunaan TIK untuk pengembangan ekonomi pertanian dan pengentasan kemiskinan, khususnya di Indonesia.

\section{METODE PENELITIAN}

Kajian ini menggunakan metode studi literatur yang bersumber dari hasilhasil penelitian yang dipublikasikan sebagai artikel jurnal yang dapat diakses secara online, antara lain: (1) Peranan teknologi informasi dan komunikasi dalam pengentasan kemiskinan petani pedesaan di Abia State, Nigeria; (2) Pengentasan kemiskinan melalui teknologi informasi dan komunikasi: Studi kasus di Nigeria, (3) Telepon mobile dan keputusan pemasaran petani di Ethiopia; (4) Dampak TIK pada kondisi sosial ekonomi pedesaan di Banglades; dan (5) Pemanfaatan teknologi informasi dan komunikasi dalam pemenuhan informasi bagi rumah tangga usaha pertanian di Kecamatan Halongonan, Indonesia.

\section{HASIL DAN PEMBAHASAN}

\section{PEMANFAATAN TIK UNTUK PENGEMBANGAN EKONOMI PERTANIAN DAN PENGENTASAN KEMISKINAN DI BEBERAPA NEGARA BERKEMBANG}

\section{Peranan TIK dalam Pengentasan Kemiskinan Petani Pedesaan di Nigeria}

Isife, Nnodim, danAlbert (2013: 20-25) melaporkan hasil penelitian mereka terkait dengan peranan TIK dalam pengentasan kemiskinan petani pedesaan di Abia State, Nigeria.Abia Statemerupakan Zona geopolitik Timur Selatan Nigeria, dibatasi menjadi tiga zona pertanian Aba, Ohafia dan Umuahia (ADP, 2004).

Populasi penelitian terdiri atas semua petani dan penyuluh di Abia State. Namun, zona pertanian Aba dipilih untuk studi dari tiga zona di negara bagian tersebut.Para petani dipilih secara sengaja dari dua daerah pemerintah daerah Ukwa-Timur dan Isialangwa Utara dari sembilan wilayah pemerintah lokal yang membentuk zona tersebut berdasarkan keragaman mereka.Sampel acak stratifikasi digunakan untuk memilih dua komunitas masing-masing dari dua pemerintah daerah yang dipilih. Sepuluh petani dipilih secara acak dari masingmasing empat komunitas (total 40 petani) dan sepuluh pekerja penyuluhan dipilih secara sengaja sehingga jumlah seluruhnya adalahlima puluh responden yang disurvei.

1) Peran TIK dalam pembangunan pedesaan dan pertanian. Temuan penelitian ini menunjukkan bahwa TIK berperan untuk: Mendapatkan akses ke pasar di luar lingkungan terdekat (52\%); Meramalkan kondisi cuaca (50\%); Mengembangkan kapasitas untuk menjangkau khalayak yang besar dan penerimaan informasi yang mudah (40\%).

2) Jenis perangkat keras dan perangkat lunak yang tersedia di area studi.Responden percaya bahwa: Komponen TIK utama yang lazim di daerah tersebut adalah radio (80\%), televisi (76\%) dan telepon GSM (70\%). Komponen lainnya adalah komputer (10\%), video (16\%), DVD/CD (22\%); proyektor $(20 \%)$ dan film/slide $(2 \%)$. Penggunaan layanan e-mail dan internet tidak mencatat respons.

3) Tingkat penggunaan TIK di wilayah studi.Data pada tingkat penggunaan TIK oleh petani dan petugas penyuluhan dianalisis menggunakan statistik rata-rata, 
dengan nilai minimum yang dapat diterima 2,5. Tingkat penggunaan TIK di antara responden adalah tinggi untuk radio $(3,00)$, televisi $(3,00)$, telepon GSM $(2,80)$ dan pesan SMS $(2,80)$. Penggunaan komputer dan proyektor dinilai rendah masing-masing $(0,70)$ dan $(0,60)$. Penggunaan CD/DVD (2.40), file/Slide (0.50) juga rendah. Penggunaan e-mail dan internet tidak mencatat respons.

4) Pengaruh TIK dalam pengentasan kemiskinan di kalangan petani pedesaan. Para responden berpendapat bahwa:

- TIK dapat memfasilitasi akses mudah ke pasar di luar domain mereka melalui transaksi bisnis on-line (64\%)

- Peningkatan kekuatan negosiasi melalui kontak langsung dengan pembeli yang menghilangkan perantara $(66 \%)$

- Peningkatan akses ke pasar $(64 \%)$

- Peningkatan laba oleh petani kecil (68\%)

- TIK memfasilitasi kontak yang mudah antara petani di satu sisi dan pemasar input pertanian dan pembeli produk $(66 \%)$.

- Dampak positif lainnya dari TIK dalam pengentasan kemiskinan termasuk penyebaran informasi yang mudah tentang kondisi pasar dan persyaratan ekspor (62\%) dan koordinasi dan sistematisasi informasi pertanian (60\%).

Dari penelitian ini dapat disimpulkan sebagai berikut.

- Adanya perangkat keras dan lunak TIK yang tersedia di wilayah studi, dalam bentuk radio, televisi, telepon sistem global mobile (GSM), telepon utama dan pesan SMS.

- Adanya tingkat penggunaan yang cukup oleh masyarakat, terutama radio, televisi, telepon GSM dan SMS.

- Komponen TIK digunakan terutama untuk meramalkan kondisi cuaca, akses pasar (untuk input dan produk), berkomunikasi dengan mudah ke audiens yang lebih lama dan untuk mobilisasi secara efektif orang-orang untuk bertindak.

- Ketika ini terjadi petani pedesaan akan meningkatkan produktivitas mereka, mengakses pasar secara online, meningkatkan kekuatan negosiasi mereka melalui kontak langsung dengan pembeli yang akan bermanifestasi ke peningkatan pendapatan dan kesejahteraan.

Selanjutnya, Abiodun dan Sunday (2013:20-24) melaporkan hasil studi mereka terkait dengan upaya pengentasan kemiskinan di Nigeria melalui TIK.Selama dekade terakhir, telah terjadi perdebatan berkelanjutan mengenai peran TIK dalam pembangunan dan di bidang peningkatan standar hidup, dan pengentasan kemiskinan di sebagian besar negara (Mohammed, 2009).

Peran spesifik TIK yang harus dimainkan dalam pengembangan masyarakat tergantung pada kegiatan yang berbeda seperti: keuangan, tujuan administratif, masalah keamanan, dan lainnya (Maung, 2007). Memberantas kemiskinan adalah tantangan terbesar yang dihadapi dunia saat ini dan persyaratan yang sangat diperlukan untuk pembangunan berkelanjutan, terutama untuk negara-negara berkembang.Memiliki informasi yang tepat pada waktu yang tepat dapat membantu mencari solusi untuk masalah kemiskinan dan TIK adalah salah satu solusinya.

Selanjutnya, penelitian ini menemukan dan menyimpulkan sebagai berikut.

1) Kasus yang kuat dapat dibuat untuk mendukung penggunaan TIK yang selektif untuk pengentasan kemiskinan yang signifikan. Dengan demikian, 
penting bahwa pemerintah mendorong sektor TIK lokal yang kuat yang mencakup semua aspek TIK untuk memastikan bahwa negara memiliki kapasitas untuk memanfaatkannya sesuai kebutuhan dalam perjuangannya terhadap kemiskinan.

2) Menggunakan TIK untuk pengentasan kemiskinan lebih efektif ketika disematkan dan disinkronkan dengan kebijakan dan sumber daya lain misalnya lingkungan yang kondusif, yang mencakup kebebasan berekspresi, pasar kompetitif, regulator independen, dana layanan universal, dan elemen lainnya.

3) Strategi penanggulangan kemiskinan nasional atau strategi sektor khusus, kepemilikan oleh komunitas lokal, kemitraan dan jaringan merupakan kunci untuk program penanggulangan kemiskinan yang efektif.

4) Pemerintah harus mengembangkan program yang menciptakan kesadaran akan manfaat TIK dan menyadarkan masyarakat tentang cara terbaik memanfaatkan fasilitas TIK yang mereka miliki.

5) Kesimpulannya, dengan lingkungan yang mendukung itu menegaskan bahwa hal itu memungkinkan, praktis, dan terjangkau untuk menggunakan TIK untuk bermanfaat bagi orang miskin. Ini adalah panggilan bagi semua negara untuk memiliki kehadiran dalam ekonomi berbasis teknologi yang sedang berkembang.

Abiodun dan Sunday (2013) merekomendasikan bahwa praktik terbaik dalam penggunaan TIK untuk mengurangi kemiskinan bagi negara adalah mengembangkan industri TIK yang kuat, lengkap dengan fasilitas digital terbaru. Industri semacam itu akan membantu memastikan bahwa semua bentuk TIK tersedia ketika dibutuhkan untuk mendukung kegiatan pengentasan kemiskinan. Sektor TIK yang aktif juga merupakan penggerak yang kuat untuk komunikasi harga yang positif, mendukung aspek sosial pengentasan kemiskinan serta solusi berbasis TIK.Sektor TIK yang kuat dan lincah adalah "enabler" yang memungkinkan penggunaan TIK yang terpilih dalam pengentasan kemiskinan. Terlebih lagi, sektor TIK harus menangani banyak kebutuhan lain di semua tingkatan, dan itu adalah "enabler" yang memungkinkan negara untuk berpartisipasi dalam ekonomi global berbasis TIK.

\section{Dampak TIK pada Kondisi Sosial Ekonomi Pedesaan di Banglades}

Rahman, Abdullah, Haroon, dan Tooheen (2013:1-8) melakukan penelitian yang bertujuan untuk mengeksplorasi dampak TIK pada perkembangan sosial ekonomi penduduk desa di Banglades.Menurut mereka, penduduk pedesaan di Bangladesh memiliki akses terbatas ke sumber daya dan ruang publik karena situasi sosio-ekonomi mereka.Penduduk pedesaan menderita diskriminasi yang parah, sebagian karena kurangnya akses ke informasi.TIK berpotensi dapat menjangkau masyarakat pedesaan dan menjawab kebutuhan pengetahuan dan informasi mereka.

Dalam penelitian ini, empat desa yang berbeda (520 responden) dari empat kabupaten di Bangladesh dipilih untuk mengetahui bagaimana TIK memainkan peran katalis dalam penyebaran informasi, transfer pengetahuan, perawatan kesehatan, peningkatan kapasitas dan tata kelola yang lebih baik.Pengumpulan data dilakukan selama bulan Desember 2011 hingga Februari 2012. Selanjutnya Rahman, Abdullah, Haroon, dan Tooheen (2013) melaporkan hasil penelitiannya terkait dampak TIK pada kondisi ekonomi pedesaan di Banglades sebagai berikut. 
Cakupan TIK di pedesaan Bangladesh Di Bangladesh Complex Annual Growth Rate (CAGR) untuk saluran telepon tetap adalah $10,9 \%$ dan untuk pelanggan seluler adalah 97,8\%. Pangsa pasar ponsel dari total telepon di berbagai negara dan dalam kasus Bangladesh, CAGR adalah 8,6\%. Data ini diambil dari Divisi Statistik UNESCAP.Temuan ini menyiratkan bahwa di Bangladesh, tingkat pertumbuhan penggunaan ponsel sangat tinggi dan memiliki pengaruh yang signifikan terhadap sektor sosial-ekonomi negara.

1) Statistik terkini tentang penggunaan TIK di Bangladesh menunjukkan:

- Adanya kecenderungan yang meningkat untuk menggunakan fasilitas komputer di daerah pedesaan Bangladesh.

- Informasi yang paling menonjol dari survei ini adalah bahwa meskipun ponsel telah diperkenalkan di negara ini pada awal tahun sembilan puluhan, telah terjadi pertumbuhan substansial penggunaan telepon seluler di masyarakat pedesaan bersama dengan penduduk kota.

- Penggunaan Internet telah sangat meningkat baik di daerah perkotaan maupun pedesaan pada survei tersebut. Penggunaan fasilitas TIK jauh lebih tinggi di daerah perkotaan dibandingkan dengan daerah pedesaan.

2) Keseluruhan TIK dan Kesadaran

Di antara hasil survei mereka menunjukkan bahwa:

- Di antara 520 responden 56,15\% adalah laki-laki dan 43,85\% adalah perempuan. Penelitian ini memiliki 196 responden dari kelompok usia 1830 tahun karena mereka mewakili generasi muda. Temuan penggunaan ponsel:

- Kelompok usia di bawah 18 tahun kebanyakan menggunakan ponsel untuk menghabiskan waktu; kelompok usia di atas 18 tahun kebanyakan menggunakannya untuk sosialisasi dan tujuan bisnis; dan kelompok usia 1830 tahun juga menggunakannya untuk tujuan hiburan. Sangat menarik untuk diketahui bahwa di atas $90 \%$ orang cenderung menggunakan fasilitas TIK untuk keperluan komunikasi sehari-hari mereka.

- Di daerah pedesaan, TIK sama sekali tidak terbatas pada panggilan telepon seluler saja (di atas 90\%), masyarakat pedesaan memiliki pengguna internet seluler yang kuat $(28,5 \%)$ dan email (35\%) meskipun penggunaan komputer agak terbatas di bawah $10 \%$ hanya karena biaya pembelian awal yang tinggi, tetapi opsi lain kurang tersedia dan kurang populer.

- Lebih dari $90 \%$ dari mereka secara teratur menggunakan telepon seluler untuk melakukan panggilan; 28\% dari mereka menggunakan internet; $35 \%$ dari mereka secara teratur menggunakan e-mail; hanya $9 \%$ dari total responden yang menggunakan komputer di rumah atau di luar.

3) Dampak TIK terhadap dalam membentuk kembali ekonomi pedesaan

Di masyarakat pedesaan, layanan TIK telah berkontribusi terhadap pembangunan ekonomi di komunitas pedesaan melalui beberapa jalan, antara lain:

- Penggunaan TIK memungkinkan penjual untuk mempelajari tentang produk baru di pasar, untuk mengantisipasi permintaan produk yang sudah ada dan yang baru, danuntuk memahami strategi penetapan harga, dan untuk berinovasi.

- Masyarakat pedesaan mendapatkan informasi yang diperlukan dan harga pasar dari portal dan situs web yang ditunjuk dengan bantuan pengusaha yang disediakan oleh pusat informasi masyarakat (CIC) di seluruh 
Bangladesh yang tersebar melalui infrastruktur TIK untuk masyarakat pedesaan.

- Lebih dari $70 \%$ orang berpikir bahwa penggunaan ponsel saja menghemat biaya perjalanan dan komunikasi mereka untuk semua kebutuhan harian.

- Di atas $80 \%$ mendukung bahwa TIK menghemat jam kerja mereka yang dapat mereka gunakan untuk kegiatan yang lebih produktif dan membantu meningkatkan kondisi ekonomi mereka.

- Aliran pengiriman uang asing menjadi lebih mudah dan lebih cepat bagi masyarakat pedesaan.Sebagian dari mereka sangat akrab dengan layanan uang cepat seperti "bKash" dan "uang tunai" oleh beberapa operator seluler.

4) Menjembatani Gap dengan Digital Divide

- Sekarang, secara umum, orang-orang tidak harus bepergian lebih dari 30$35 \mathrm{~km}$ ke markas kabupaten untuk mendapatkan informasi tentang pendidikan, kesehatan, pekerjaan, layanan pemerintah, dan lainnya. TIK telah menghemat waktu dan uang mereka sehingga mengurangi risiko perjalanan.

- Sekarang warga dapat membuka rekening bank dengan menggunakan ponsel dan mengirim uang, serta mengajukan permohonan paspor mereka dari markas pusat Upazila.Setiap kantor pusat Upazila memiliki situs web sebagai dukungan penuh bagi warga.

- Bahkan di tahun 90an jelas terlihat bahwa desa tertinggal di belakang kota dalam hal koordinasipembangunan, fasilitas perawatan kesehatan, pendidikan, dan lainnya. Tetapi sekarang dengan menggunakan perangkat digital dan dengan dampak TIK, semua standar kehidupan di daerah pedesaan Bangladesh meningkat dan membantu menjembatani kesenjangan antara daerah perkotaan dan pedesaan.

Dari hasil penelitian ini dapat disimpulkan bahwa Akses ke layanan data mendorong konten lokal, memungkinkan pengguna untuk belajar tentang layanan lokal seperti layanan kesehatan, layanan-pertanian, serta standar pendidikan dan pengetahuan umum. Akses ke layanan data memungkinkan organisasi untuk memberikan informasi dasar seperti perlindungan terhadap kondisi berbahaya seperti flu burung dan penyakit lainnya, waktu operasi dan cara mendapatkan vaksinasi.

Layanan seluler dapat diperluas ke seluruh populasi dan yang akan berkontribusi untuk meningkatkan semua indikator sosial ekonomi. Negara berkembang seperti Bangladesh dapat menggunakan TIK untuk mengubah mobilitas keuangan mikro menjadi mobilitas makro menjadi negara berpenghasilan menengah dari tingkat miskin.

\section{Telepon Mobile dan Keputusan Pemasaran Petani di Ethiopia}

Tadesse dan Bahiigwa (2015: 296-307) melakukan penelitian terkait dengan pemanfaatan telepon mobile dalam pembuatan keputusan pemasaran petani di Ethiopia. Mereka menyatakan bahwa akses terhadap informasi merupakan input penting untuk membuat keputusan pertanian dalam produksi, pemasaran, dan keuangan, dan secara historis sangat mahal di Afrika Selatan Sahara. Petani yang ingin menjual produknya harus mencari harga yang tepat, pembeli yang tepat, standar dan nilai produk yang tepat.Petani harus sering bepergian, mengulang dan membongkar barang untuk memamerkan hasil panen 
mereka kepada pembeli dan pialang.Petani-petani biasa di Ethiopia menjual produk ke pedagang baik di desa mereka atau di pasar yang jauh yang memerlukan biaya transportasi dan tenaga kerja yang besar.Pasar desa dicirikan oleh informasi asimetris di mana pedagang lebih banyak informasi daripada petani tentang harga di pasar pusat atau regional (Tadesse \& Shively, 2013) yang membuat pencarian informasi menjadi sangat mahal.Perluasan jangkauan ponsel dianggap sebagai salah satu solusi untuk masalah informasi semacam itu.

Data yang digunakan dalam penelitianTadesse dan Bahiigwa (2015) ini diambil dari survei rumah tangga yang dilakukan pada tahun 2012 di Ethiopia Tengah di mana petani dianggap sebagai produsen surplus. Survei ini dilakukan sebagai studi dasar untuk proyek yang bertujuan memberdayakan petani kecil melalui pengorganisasian koperasi dan memperkenalkan TIK untuk pemasaran pertanian.Teknik pengambilan sampel multistage digunakan untuk memilih sampel rumah tangga.

Sampel rumah tangga diwawancarai oleh enumerator berpengalaman dan terlatih yang dipekerjakan untuk tujuan ini dengan menggunakan kuesioner terstruktur dan pretest. Kuesioner yang digunakan untuk mengumpulkan data sangat kaya dan mengandung banyak variabel yang terkait dengan akses pasar, pencarian informasi, praktik pemasaran, dan nilai total yang dijual untuk tanaman yang berbeda. Penggunaan telepon seluler untuk pencarian informasi secara khusus ditanyakan untuk memahami peran TIK dalam mengakses pasar.Informasi demografi dan sosial ekonomi lainnya juga dikumpulkan.

Hasil dan simpulan dari penelitan Tadesse dan Bahiigwa (2015), antara lain sebagai berikut.

1) Menerjemahkan peluang teknologi menjadi manfaat ekonomi selalu menjadi tantangan pembangunan dalam pertanian skala kecil. Banyak petani memiliki ponsel tetapi sejauh mana ponsel ini membantu para petani dalam membuat keputusan pemasaran merupakan masalah penting yang banyak peneliti dan praktisi pembangunan ingin pahami lebih lanjut. Makalah ini menilai dampak dari akses telepon seluler baik di tingkat rumah tangga dan desa pada keputusan pemasaran dan harga yang diterima oleh petani di Ethiopia. Hasilnya beragam. Namun, secara umum, dampaknya tidak cukup kuat untuk percaya bahwa ponsel benar-benar membantu keputusan pemasaran petani. Analisis empiris pada harga gerbang pertanian jelas menunjukkan bahwa dampaknya hampir selalu tidak signifikan. Temuan-temuan ini menunjukkan bahwa telepon seluler mungkin berguna bagi petani tertentu dalam beberapa jenis keadaan tertentu tetapi di daerah penelitian telepon seluler tampaknya tidak menjadi saluran penting untuk mengakses informasi harga. Ketiadaan ponsel sebagai alat efektif penemuan harga menunjukkan bahwa ada ruang lingkup untuk sarana alternatif untuk memberikan informasi harga.

2) Lebih jauh lagi, penjelasan tentang tidak adanya ponsel sebagai sarana efektif untuk mengakses informasi harga bisa jadi adalah terbatasnya penggunaan telepon seluler untuk mencari informasi pertanian. Hanya sedikit petani yang menggunakan ponsel untuk mengurangi biaya pencarian informasi. Hal ini tampaknya karena kurangnya sumber informasi yang dapat menyampaikan informasi yang relevan kepada petani. Oleh karena itu, Tadesse dan Bahiigwa (2015) merekomendasikan pembentukan pusat informasi baik di pusat koperasi petani atau di pusat pengembangan pertanian lokal yang melayani petani sebagai sumber informasi dan pengetahuan yang dapat diandalkan. 
3) Dampak lemah dari akses telepon seluler pada manfaat petani juga dapat dikaitkan dengan fakta bahwa efisiensi yang dibuat karena ponsel dapat disesuaikan oleh pedagang lebih daripada petani. Dalam hal ini, tindakan kebijakan diperlukan untuk meningkatkan distribusi peningkatan pasar di kalangan petani dan pedagang lokal.

\section{Pemanfaatan TIK dalam Pemenuhan Informasi Bagi Rumah Tangga Usaha Pertanian di Indonesia}

Di Indonesia, penelitian terkait pemanfaatan TIK bagi usaha pertanian anntara lain dilakukan oleh Harahap (2016: 77-88). Pemanfaatan Teknologi Informasi dan Komunikasi dalam Pemenuhan informasi bagi rumah tangga usaha pertanian di Kecamatan Halongonan, Kabupaten Padang Lawas Utara, Provinsi Sumatera Utara dilatarbelakangi oleh kondisi wilayah yang sebagian besar berbukit-bukit.Mata pencaharian masyarakatnya adalah petani.Untuk memenuhi kebutuhan informasi pertanian, selain mendapatkannya dari petugas penyuluh lapangan (PPL), para rumah tangga desa berharap mendapatkan akses informasi dari perkembangan TIK.Perkembangan TIK seperti televisi, radio dan internet seyogianya dapat meningkatkan kualitas maupun kuantitas hasil pertanian. Penelitian ini bertujuan untuk mendeskripsikan pemanfaatan TIK dalam pemenuhan informasi bagi rumah tangga usaha pertanian di Kecamatan Halongonan dalam pemenuhan informasi pertanian bagi rumah tangga usaha pertanian di lokasi penelitian.

Penelitian ini menggunakan pendekatan kuantitatif deskriptif dengan metode survei. Lokasi penelitian berdasarkan perwakilan desa yang topografinya berbukit-bukit dengan cara undi meliputi Desa Sitabola, Japinulik, Sitenun, Sandean Tonga, Tapus Jae, dan Sandean Julu Kecamatan Halongonan. Pengumpulan data penelitian dilaksanakan pada bulan Juli 2015.Populasi penelitian berjumlah 134 rumah tangga di lokasi penelitian.Teknik penetapan sampel ditentukan jumlah sampel yang dihitung dengan rumus Taro Yamane berjumlah 100 responden.Teknik pemilihan responden menggunakan metode Kish Grid. berikut.

Hasil penelitian Harahap (2016: 77-88) memberikan informasi sebagai

1) Kepemilikan TIK

Kepemilikan teknologi informasi dan komunikasi bagi rumah tangga usaha pertanian di kecamatan Halongonan yaitu: televisi sebanyak 75 responden (75\%) dan 25 responden (25\%) tidak memiliki televisi; kepemilikan radio sebanyak 25 responden (25\%) dan 75 responden (75\%) tidak memiliki radio; dan kepemilikan akses internet (telepon selular, tablet, PDA/smartphone) sebanyak 12 responden (12\%) dan 88 responden (88\%) yang tidak memiliki.

2) Pemanfaatan TV

Pemanfaatan televisi dalam jumlah waktu yang digunakan untuk menonton televisi setiap hari sebanyak 65 responden $(86,7 \%)$, 2-3 kali seminggu sebanyak 7 responden $(9,3 \%)$, minimal 1 minggu sekali sebanyak 3 responden $(4,0 \%)$.

3) Pemanfaatan Radio

Pemanfaatan radio dalam jumlah waktu yang digunakan untuk mendengarkan radio dengan frekuensi 2-3 kali seminggu sebanyak 12 responden (48\%), minimal sekali dalam seminggu sebanyak 8 responden (32\%) dan setiap hari sebanyak 5 responden (20\%). 
4) Pemanfaatan akses internet

Pemanfaatan akses internet oleh responden sangat minim sekali yaitu lebih dari 1 kali dalam seminggu sebanyak 8 responden $(66,7 \%)$, setiap hari sebanyak 3 responden (25\%) dan minimal 1 kali dalam seminggu sebanyak 1 responden $(8,3 \%)$.

5) Minat baca surat kabar

Minat baca surat kabar dari sebanyak 100 responden (100\%) hanya 16 responden (16\%) dan membeli surat kabar hanya 6 responden $(6 \%)$ saja. Artinya, pemanfaatan media surat kabar sangat tidak maksimal oleh rumah tangga usaha pertanian.

Berdasarkan temuan penelitian ini dapat dimaknai bahwa pemanfaatan TIK (televisi, radio, media Internet) dalam pemenuhan informasi bagi rumah tangga usaha pertanian di Kecamatan Halongonan Kabupaten Padang Lawas Utara masih sangat rendah.TIK belum dimanfaatkan secara optimal untuk pengembangan usaha pertanian.Menurut Harahap (2016) penyebabnya adalah rendahnya tingkat pendidikan rumah tangga usaha pertanian dan akses informasi yang rendah terhadap media internet.Untuk mengatasi kesenjangan informasi bagi rumah tangga/masyarakat desa khususnya desa-desa dengan topografi berbukit-bukit khususnya Kecamatan Halongonan,Harahap (2016) menyarankan untuk mengefektifkan petugas penyuluh lapangan danpembangunan infrastruktur telekomunikasi dalam rangka penguatan signal telekomunikasi.

\section{LESSONS LEARNED: PELUANG DAN TANTANGAN PEMANFAATAN TIK UNTUK PENGEMBANGAN EKONOMI PERTANIAN DAN PENGENTASAN KEMISKINAN}

Berdasarkan lesson learned dari hasil-hasil penelitian pemanfaatan TIK untuk pengembangan ekonomi pertanian dan pengentasan di beberapa negara berkembang dapat diambil pelajaran, antara lain sebagai berikut.

- Dengan meningkatnya pasar untuk produk mereka, petani memiliki kekuatan untuk bernegosiasi lebih baik, meningkatkan pendapatan mereka, dan dengan demikian meningkatkan standar hidup mereka. Temuan ini tampaknya setuju dengan pandangan dan harapan para pemangku kepentingan dalam pembangunan pedesaan bahwa berbagai kekuatan sedang bekerja untuk mengubah pembangunan pertanian dari proses transfer teknologi ke proses memfasilitasi berbagai komunikasi, informasi dan layanan advokasi, dengan tujuan akhir untuk meningkatkan standar hidup seluruh masyarakat pedesaan.

- Dalam hal perkiraan cuaca, TIK memainkan peran dalam membantu petani dalam pengambilan keputusan, dalam kaitannya dengan waktu penanaman dan panen karena ini penting dalam pembangunan pertanian. Dalam hal ini, TIK memberdayakan petani dengan aset produktif dan pemasaran, meningkatkan kapasitas produktif mereka, sehingga mengurangi status kemiskinan mereka.

- Meskipun ditemui adanya kecenderungan penggunaan intenet dan email melalui telepon seluler, di lokasi penelitian yang berbeda, para petani di daerah pada umumnya tidak memiliki kapasitas untuk menggunakan e-mail atau layanan internet untuk komunikasi. Dimasukkannya-antara lain radio, televisi, telepon sebagai TIK digunakan untuk diseminasi, transfer dan berbagi informasi pembangunan.Melalui radio, televisi, telepon (GSM dan jalur utama) dan komunikasi melalui pesan SMS, petani memiliki banyak 
kesempatan untuk mengakses informasi pembangunan penting berkaitan dengan kegiatan mata pencaharian mereka. TIK mungkin menjadi solusi untuk masalah mengakses berbagai sumber informasi yang terjangkau, relevan dan dapat diandalkan oleh petani.

- Sangat menarik untuk diketahui bahwa kebanyakan orang cenderung menggunakan fasilitas TIK untuk keperluan komunikasi sehari-hari mereka dan hiburan.

- Layanan TIK yang terjangkau di masyarakat pedesaan telah memainkan peran yang sangat kuat dalam meningkatkan kondisi ekonomi penduduk yang berkontribusi pada ekonomi pedesaan.

- Komponen TIK digunakan terutama untuk meramalkan kondisi cuaca, akses pasar (untuk input dan produk), berkomunikasi dengan mudah ke audiens yang lebih lama dan untuk mobilisasi efektif dari orang-orang untuk bertindak. Ketika ini terjadi petani pedesaan dapat meningkatkan produktivitas mereka, mengakses pasar secara online, meningkatkan kekuatan negosiasi mereka melalui kontak langsung dengan pembeli yang akan bermanifestasi ke peningkatan pendapatan dan kesejahteraan.

- Akses ke layanan data mendorong konten lokal, memungkinkan pengguna untuk belajar tentang layanan lokal seperti layanan kesehatan, layananpertanian, serta standar pendidikan dan pengetahuan umum. Akses ke layanan data memungkinkan organisasi untuk memberikan informasi dasar seperti perlindungan terhadap kondisi berbahaya seperti flu burung dan penyakit lainnya, dan cara mendapatkan vaksinasi.

- Layanan seluler dapat diperluas ke seluruh populasi dan pada gilirannyaberkontribusi untuk meningkatkan semua indikator sosial ekonomi. Negara berkembang dapat menggunakan TIK untuk mengubah mobilitas keuangan mikro menjadi mobilitas makro menjadi negara berpenghasilan menengah dari tingkat miskin.

- Secara umum, dampak ponsel tidak cukup kuat untuk membantu keputusan pemasaran petani. Analisis empiris pada harga gerbang pertanian jelas menunjukkan bahwa dampak ponsel hampir selalu tidak signifikan. Temuantemuan ini menunjukkan bahwa telepon seluler mungkin berguna bagi petani tertentu dalam beberapa jenis keadaan tertentu tetapi di daerah penelitian telepon seluler tampaknya tidak menjadi saluran penting untuk mengakses informasi harga. Ketiadaan ponsel sebagai alat efektif penemuan harga menunjukkan bahwa ada ruang lingkup untuk sarana alternatif untuk memberikan informasi harga.

- Lebih jauh lagi, penjelasan tentang tidak adanya ponsel sebagai sarana efektif untuk mengakses informasi harga bisa jadi adalah terbatasnya penggunaan telepon seluler untuk mencari informasi pertanian. Hanya sedikit petani yang menggunakan ponsel untuk mengurangi biaya pencarian informasi. Hal ini tampaknya karena kurangnya sumber informasi yang dapat menyampaikan informasi yang relevan kepada petani. Oleh karena itu, pembentukan pusat informasi baik di pusat koperasi petani atau di pusat pengembangan pertanian lokal yang melayani petani sebagai sumber informasi dan pengetahuan yang dapat diandalkan.

- Menggunakan TIK untuk pengentasan kemiskinan lebih efektif ketika disematkan dan disinkronkan dengan kebijakan dan sumber daya lain misalnya lingkungan yang kondusif, yang mencakup kebebasan berekspresi, 
pasar kompetitif, regulator independen, dana layanan universal, dan elemen lainnya.

- Pemerintah harus mengembangkan program yang menciptakan kesadaran akan manfaat TIK dan menyadarkan masyarakat tentang cara terbaik memanfaatkan fasilitas TIK yang mereka miliki.Dengan lingkungan yang mendukung,memungkinkan, praktis dan terjangkau,penggunaan TIK bermanfaat bagi orang miskin.

- TIK memiliki potensi untuk menjadi instrumen yang efektif dalam mendukung pengentasan kemiskinan. Sifat TIK yang fleksibel memungkinkan mereka untuk membantu mengatasi masalah dalam kesehatan, pendidikan, pemerintahan, keamanan, dan lain-lain. Selain itu, mereka dapat memungkinkan pemberdayaan masyarakat, memperkuat hak asasi manusia dan membawa perdamaian ke dunia secara luas.

- Khususnya di Indonesia, pemanfaatan TIK (televisi, radio, media Internet) dalam pemenuhan informasi bagi rumah tangga usaha pertanian di Kecamatan Halongonan Kabupaten Padang Lawas Utara sangat rendah. Penyebabnya adalah rendahnya tingkat pendidikan rumah tangga usaha pertanian dan akses informasi yang rendah terhadap media internet.

\section{KESIMPULAN DAN SARAN}

Studi di beberapa negara berkembang mengonfirmasi bahwa TIK memainkan peran dalam membantu petani dalam pengambilan keputusan, dalam kaitannya dengan waktu penanaman dan panen karena ini penting dalam pembangunan pertanian.Dalam hal ini, TIK memberdayakan petani dengan aset produktif dan pemasaran, meningkatkan kapasitas produktif mereka, sehingga mengurangi status kemiskinan mereka.Layanan TIK yang terjangkau di masyarakat pedesaan telah memainkan peran yang sangat kuat dalam meningkatkan kondisi ekonomi penduduk yang berkontribusi pada ekonomi pedesaan.Melalui radio, televisi, telepon (GSM dan jalur utama) dan komunikasi melalui pesan SMS, petani memiliki banyak kesempatan untuk mengakses informasi pembangunan penting berkaitan dengan kegiatan mata pencaharian mereka.TIK mungkin menjadi solusi untuk masalah mengakses berbagai sumber informasi yang terjangkau, relevan dan dapat diandalkan oleh petani.Dengan demikian, TIK memiliki potensi untuk menjadi instrumen yang efektif dalam mendukung pengentasan kemiskinan. Memanfaatkan TIK untuk pengentasan kemiskinan lebih efektif ketika disematkan dan disinkronkan dengan kebijakan dan sumber daya lain misalnya lingkungan yang kondusif, yang mencakup kebebasan berekspresi, pasar kompetitif, regulator independen, dana layanan universal, dan elemen lainnya.

Di Indonesia, pemanfaatan TIK (televisi, radio, media Internet) dalam pemenuhan informasi bagi rumah tangga usaha pertanian di kawasan pedesaan masih relatif minimal. TIK belum dimanfaatkan secara optimal untuk pengembangan usaha pertanian.Penyebabnya adalah rendahnya tingkat pendidikan rumah tangga usaha pertanian dan akses informasi yang rendah terhadap media internet.Untuk mengatasi kesenjangan informasi bagi rumah tangga/ masyarakat desa khususnya desa-desa dengan topografi berbukit-bukit adalah lebihmengefektifkan petugas penyuluh lapangan,mengakselerai pembangunan infrastruktur telekomunikasi dalam rangka penguatan signal telekomunikasi, dan memberikan dukungan secara terus-menerus kepada petani pedesaan dan usaha pertanian. Pemerintah harus mengembangkan program yang 
menciptakan kesadaran akan manfaat TIK dan menyadarkan masyarakat tentang cara terbaik memanfaatkan fasilitas TIK yang mereka miliki.

\section{DAFTAR PUSTAKA}

Abiodun, O.O., \& Sunday, A.I. 2013. Poverty Alleviation through Information and Communications Technology: A Case Study of Nigeria. International Journal of Multidisciplinary Sciences and Engineering, August 2013, 4(7), 20-24

Adeniyi, O.B. 2010.Potentials of information and communication technology for poverty alleviation and food security.Journal of Agricultural Extension 14(2), 131-139.

Asian Development Bank. 2003. A strategic approach to information and communication technology. Toward e-development in Asia and the pacific.

Harahap A.R. 2016. Pemanfaatan teknologi informasi dan komunikasi dalam pemenuhan informasi bagi rumah tangga usaha pertanian di Kecamatan Halongonan.Penelitian Komunikasi dan Pembangunan, 17(2), 77-88.

Harris, R. 2002. A framework for poverty alleviation with ICTs [Internet].Roger Harris Associates,

Hong

Kong.http.//www.tanzaniagateway.org/docs/framework_for_pover ty_alleviation_with_ICTs.pdf] [Diakses pada 6 May 1018].

Isife, B.I., Nnodim, A.,\& Albert, C. 2013. The role of ict in poverty alleviation among rural farmers in Abia State.Computer Engineering and Intelligent Systems, 4(7), $20-25$.

Kementerian Komunikasi dan Informatika RI. 2015. Pemanfaatan dan Pemberdayaan Teknologi Informasi dan Komunikasi pada Petani dan Nelayan (Survey Rumah Tangga dan Best Practices) Edisi 2015. Jakarta: Pusat Penelitian dan Pengembangan Penyelenggaraan Pos dan Informatika Badan Penelitian dan Pengembangan Sumber Daya Manusia Kementerian Komunikasi dan Informatika.

Leary, J. \& Berge, Z.L. 2006.Trends and challenges of e-learning in national and international agricultural development.Internal Journal of Education and $\begin{array}{llll}\text { Development Using } \quad I C T, & \text { 2(2). Retrieved }\end{array}$ http://ijeduct:dec.uwi.edu/viewarticle.php?id=179\& layout html on 8/1/2007.

Madukwe, M.C. 2006. Delivery of agricultural extension services to farmers in developing countries; Issues for considerations."Knowledge for development" Observatory on Science and Technology.http//knowledge cta.int/tr/content/view/full/3009.

Maung, K.S. 2007.Revisiting the role of ICT in development: 9th international conference on social implications of computers in developing countries, Sau Paulo, Brazi.Retrieved on 30th January, 2018 from www.ifipwg94. org.br/fullpapers/R0094-1.pdf.

McNamara, M.S. 2003. Information and communication technologies-poverty and development: Learning from experience. Background paper prepared for the Information Development Annual Symposium,Dec. 9-10 (2003) Geneva Switzerland.

Mohammed, S. 2009. Poverty alleviation in nigeria: the role of information communication technology, Retrieved on 12th February, 2018 from www.abu.edu.ng/publications/2009-06-23-112611_373.doc.

Mulyandari, R.S., Sumardjo, Panjaitan, N.K., dan Lubis, D.P. 2010. Implementasi Cyber Extension dalam Komunikasi Inovasi Pertanian.Informatika Pertanian, Volume 19, No. 2, IPB. 
pISSN 1693-3699

Jurnal Komunikasi Pembangunan

elSSN 2442-4102

Juli 2018, Volume 16, No. 2

Rahman, A., Abdulla, M.N., Haroon, A., dan Tooheen, R.B. 2013.ICT impact on socioeconomic conditions of rural Bangladesh.Journal of World Economic Research, 2(1), 1-8.

Sumardjo, Baga, L.M. dan Mulyandari R.S.H. 2010. Cyber Extension: Peluang dan Tantangan dalam Revitalisasi Penyuluhan Pertanian. Bogor: PT Penerbit IPB Press.

Tadesse, G., \& Bahiigwa, G. 2015. Mobile phones and farmers' marketing decisions in Ethiopia.World Development, 68, 296-307.

Tadesse, G., \& Shively, G. 2013. Repeated transaction in rural grain market of Ethiopia.Journal of Development Studies, 49(9), 1172-1187. 